\section{Mekanisme Pengaduan Oleh Committee Against Torture Terkait Tindakan Penyiksaan dan Perlakuan yang Merendahkan Martabat Manusia}

Halaman | 36

PT. Infokom Elektrindo (MNC Group), aldoricogeraldi91@ gmail.com

\begin{abstract}
This research aims to analyze the form of complaints mechanism by the Committee Against Torture. This research is a study that uses normative legal research by collecting secondary data. Data collection is done using the library study method by collecting legal materials and information in the form of primary, secondary, and tertiary legal materials. In order to get a clear explanation, the data is then arranged systematically and analyzed using descriptive methods. The results of this research indicate that torture is an act carried out by causing pain or suffering. The United Nations General Assembly then established the Convention against Torture which is believed to be able to specifically monitor multilateral instruments for the protection of torture and other inhuman treatment. Furthermore, related to the complaints mechanism regulated by the Anti-Torture Committee that complaints procedures in international law generally refer to a formal legal process whereby a person or group of people submit a complaint to an international legal entity to reveal that their human rights have been violated in a particular case. The Committee has a mandate related to the assessment of complaints filed by participating countries that have recognized the authority of the Committee, individuals and the Committee can conduct fact-finding if it has reliable information about the occurrence of systematic torture in one of the participating countries.
\end{abstract}

Keywords: Torture; Convention Against Torture; Committee Against Torture

\begin{abstract}
Abstrak
Penelitian ini bertujuan untuk menganalisis mekanisme pengaduan yang dilakukan oleh Committee Against Torture. Penelitian ini merupakan penelitian yuridis normatif yang dilengkapi data sekunder. Metode penelitian menggunakan studi pustaka dengan mengumpulkan bahan hukum dan informasi berupa bahan hukum primer, sekunder, dan tersier. Untuk mendapatkan penjelasan yang jelas, data kemudian disusun secara sistematis dan dianalisis menggunakan metode deskriptif. Hasil penelitian ini menunjukkan bahwa penyiksaan merupakan tindakan yang dilakukan dengan menimbulkan rasa sakit atau penderitaan. Majelis Umum Perserikatan Bangsa-Bangsa kemudian membentuk Konvensi Menentang Penyiksaan yang diyakini mampu secara khusus memantau instrumen multilateral untuk perlindungan penyiksaan dan perlakuan tidak manusiawi lainnya. Lebih lanjut, terkait mekanisme pengaduan yang diatur oleh Committee Against Torture bahwa prosedur pengaduan dalam hukum internasional pada umumnya mengacu pada proses hukum formil dimana seseorang atau sekelompok orang mengajukan pengaduan ke badan hukum internasional untuk mengungkapkan bahwa hak asasi mereka telah dilanggar dalam kasus tertentu. Komite memiliki mandat terkait dengan penilaian pengaduan yang diajukan oleh negara peserta yang telah mengakui kewenangan Komite, individu dan Komite dapat melakukan pencarian fakta jika memiliki informasi yang dapat dipercaya tentang terjadinya penyiksaan sistematis di salah satu negara peserta.

Kata kunci: Penyiksaan; Konvensi Menentang Penyiksaan; Committee Against Torture
\end{abstract}

\section{Jurnal YUSTIKA Media Hukum dan Keadilan Fakultas Hukum Universitas Surabaya Vol. XX No. X, Desember 201X P-ISSN: xxxxx, E-ISSN: $x x x-x x x x$}


Jurnal Yustika

Vol. 23 No. 01, Juli 2020

Halaman | 37

Mekanisme

Pengaduan Oleh

Committee Against

Torture Terkait

Tindakan

Penyiksaan Dan

Perlakuan Yang

Merendahkan

Martabat Manusia

Aldo Rico Geraldi

\section{Pendahuluan}

Penyiksaan secara universal telah dianggap sebagai pelanggaran berat hak asasi manusia. Para penandatangan Konvensi Jenewa Ketiga dan Konvensi Jenewa Keempat telah menyetujui untuk tidak melakukan penyiksaan terhadap orang yang dilindungi, seperti penduduk sipil musuh atau tawanan perang dalam suatu konflik bersenjata. Penandatanganan Konvensi Menentang Penyiksaan juga telah menyetujui untuk tidak secara sengaja memberikan rasa sakit atau penderitaan pada siapapun, untuk mendapatkan informasi atau pengakuan, menghukum, atau memaksakan sesuatu dari mereka atau orang ketiga.

Penghapusan praktik penyiksaan di dunia adalah salah satu tantangan utama yang diambil oleh Perserikatan Bangsa-Bangsa (PBB) dalam beberapa tahun setelah berdirinya. Dalam rangka untuk memastikan perlindungan yang memadai bagi semua orang dari penyiksaan dan perlakuan atau hukuman lain yang kejam, tidak manusiawi, dan merendahkan martabat manusia, selama bertahun-tahun PBB telah mengadopsi standar universal yang diwujudkan dalam Deklarasi dan Konvensi Internasional. Majelis Umum Perserikatan BangsaBangsa menerapkan hal tersebut dengan membentuk Konvensi Menentang Penyiksaan dan Perlakuan atau Hukuman Lain yang Kejam, Tidak Manusiawi dan Merendahkan Martabat Manusia pada tanggal 10 Desember 1984 yang bertujuan untuk mengurangi penyiksaan yang terjadi (Fact Sheet No.17. The Committee Against Torture, Introduction).

Sebagai suatu catatan Konvensi Menentang Penyiksaan dan Perlakuan atau Penghukuman Lain yang Kejam, Tidak Manusiawi atau Merendahkan Martabat Manusia (Convention Against Torture and Other Cruel, Inhuman or Degrading Treatment or Punishment) tahun 1984, diterima oleh Majelis Umum PBB melalui Resolusi Nomor 39/46 pada tanggal 10 Desember 1984 dan mulai berlaku pada tanggal 26 Juni 1987. Dalam perkembangannya, Konvensi Menentang Penyiksaan telah ditandatangani oleh 83 negara dari 165 negara peserta (United Nations Human Rights. Status of Ratification Convention against Torture and Other Cruel, Inhuman or Degrading Treatment or Punishment).

Dalam mengembangkan instrumen tersebut, Perserikatan Bangsa-Bangsa tidak hanya menerapkan konvensi secara tertulis, tetapi pelaksanaan dan ketaatan terhadap Konvensi tersebut juga perlu dijamin. Sehingga, dibentuklah badan pengawas yang disebut dengan Komite Menentang Penyiksaan (Committee Against Torture) yang memiliki fungsi utama untuk memastikan, mengawasi dan menerima laporan bahwa negara-negara peserta Konvensi Menentang Penyiksaan dan Perlakuan atau Hukuman Lain yang Kejam, Tidak Manusiawi dan Merendahkan Martabat Manusia telah menaati dan melaksanakan isi dari Konvensi tersebut. Komite mengadakan pertemuan untuk pertama kalinya pada bulan April 1988 di Jenewa dan sejak itu melakukan kegiatan intensif terhadap pelaksanaan Konvensi (Fact Sheet No.17. The Committee Against Torture, Introduction).

Mengenai Komite, lembaga ini dibentuk berdasarkan Pasal 17 CAT yang diamanatkan untuk memberikan rekomendasi kepada negara pihak agar mengambil langkah-langkah tertentu untuk menyelesaikan pelanggaran terhadap CAT. Komite ini beranggotakan sepuluh pakar independen. Dalam rangka pelaksanaan mandat pemantauannya, Komite memeriksa laporan berkala pelaksanaan CAT di negara-negara pihak, membuat komentar umum atas laporan tersebut dan menyampaikannya kepada negara pihak yang bersangkutan.

Dalam hal Komite menerima informasi yang dapat dipercaya tentang adanya indikasi mengenai terjadinya praktik penyiksaan secara sistematis di wilayah suatu negara pihak, maka Komite meminta agar negara pihak yang bersangkutan bekerjasama dengan komite guna 
menyelidiki informasi tersebut dan negara pihak yang bersangkutan akan menyampaikan tanggapannya. Dengan persetujuan negara pihak yang bersangkutan, penyelidikan yang dilakukan meliputi kemungkinan kunjungan ke wilayah negara pihak yang bersangkutan (Institute for Policy Research and Advocacy. Optional Protocol Convention Againts Torture).

Meskipun Komite Menentang Penyiksaan memiliki hak untuk meminta negara yang diindikasi telah terjadi suatu tindak penyiksaan, perlakuan atau hukuman lain yang kejam, tidak manusiawi dan merendahkan martabat manusia di wilayahnya untuk bekerjasama dengan komite guna menyelidiki informasi tersebut, namun Komite hanya memiliki kewenangan untuk melakukan penyelidikan di negara yang menjadi peserta Konvensi. Selain itu, prosedur pengaduan melalui Komite Menentang Penyiksaan ini tidak dimaksudkan untuk menjadi upaya perlindungan yang utama, melainkan pengaduan hanya diterapkan pada kondisi jika tidak dimungkinkan untuk mendapatkan penyelesaian di tingkat nasional.

Pengaduan yang diterima oleh Komite Menentang Penyiksaan hanya dapat dilakukan dan berlaku dalam hal negara peserta telah mengakui kewenangan Komite untuk menerima dan mempertimbangkan pengaduan yang menyebutkan bahwa suatu negara pihak menyatakan bahwa suatu negara pihak lain tidak memenuhi kewajiban-kewajibannya berdasarkan Konvensi. Komite juga tidak berhak menerima dan membahas laporan pengaduan dari seseorang, kecuali jika Komite menyatakan bahwa pengaduan tersebut belum pernah atau tidak sedang dibahas oleh prosedur penyelesaian atau penyelidikan internasional lainnya dan perorangan yang dimaksudkan sudah menggunakan segala upaya penyelesaian hukum di dalam negerinya.

Berdasarkan uraian latar belakang diatas, menjadi hal yang penting untuk melakukan pembahasan atau analisis lebih lanjut mengenai Mekanisme Pengaduan Oleh Committee Against Torture Terkait Tindakan Penyiksaan Dan Perlakuan Yang Merendahkan Martabat Manusia karena adanya ketentuan atau persyaratan tertentu yang harus dipenuhi untuk melakukan pengaduan kepada Komite mengenai adanya indikasi telah terjadi suatu tindak penyiksaan, perlakuan atau hukuman lain yang kejam, tidak manusiawi dan merendahkan martabat manusia di wilayah suatu negara. Oleh karena itu, penulis tertarik untuk melakukan analisis atau mengangkat permasalahan mengenai bagaimana pengaturan terkait penyiksaan dan mekanisme pangaduan yang diatur oleh Komite Menentang Penyiksaan dalam Konvensi Menentang Penyiksaan dan Perlakuan atau Hukuman Lain yang Kejam, Tidak Manusiawi dan Merendahkan Martabat Manusia.

\section{Metode Penelitian}

Tulisan ini adalah hasil dari sebuah penelitian hukum normatif dengan mengkaji suatu aturan-aturan, prinsip-prinsip, dan doktrin-doktrin hukum yang terkait dengan permasalahan dalam penelitian ini untuk menghasilkan suatu argumentasi (Ratna Artha Windari dan Aldo Rico Geraldi, 2017:483-484). Pengumpulan data dilakukan dengan menggunakan metode studi kepustakaan dengan mengumpulkan bahan hukum dan informasi yang berupa bahan-bahan hukum primer, sekunder, maupun tersier (Aldo Rico Geraldi, 2017:4). Dalam rangka mendapatkan pemaparan yang jelas, data tersebut kemudian disusun secara sistematis dan dianalisis dengan menggunakan metode deskriptif (Aldo Rico Geraldi, 2017:93). 
Jurnal Yustika

Vol. 23 No. 01, Juli 2020

Halaman I 39

Mekanisme

Pengaduan Oleh

Committee Against

Torture Terkait

Tindakan

Penyiksaan Dan

Perlakuan Yang

Merendahkan

Martabat Manusia

Aldo Rico Geraldi

\section{Hasil Penelitian dan Pembahasan}

\subsection{Penyiksaan}

Hak untuk tidak disiksa merupakan salah satu HAM yang bersifat pokok dan telah diatur dalam berbagai instrument HAM Internasional. Pasal 5 UDHR menyatakan bahwa tidak seorang pun boleh disiksa atau diperlakukan secara kejam, memperoleh perlakuan atau dihukum secara tidak manusiawi atau direndahkan martabatnya (no one shall be subjected to torture or to cruel, inhuman or degrading treatment or punishment). Pengaturan mengenai hal tersebut juga terdapat dalam Pasal 7 ICCPR yang menambah redaksional UDHR dengan menyatakan bahwa tidak seorang pun yang dapat dikenakan penyiksaan atau perlakuan atau hukuman lain yang keji, tidak manusiawi atau merendahkan martabat. Pada khususnya, tidak seorang pun dapat dijadikan obyek eksperimen medis atau ilmiah tanpa persetujuan yang diberikan secara bebas (no one shall be subjected to torture or to cruel, inhuman or degrading treatment or punishment. In particular, no one shall be subjected without his free consent to medical or scientific experimentation) (Rhona K. M. Smith, 2010:47).

Larangan penyiksaan merupakan norma hukum internasional yang berkategori jus cogens, yang bermakna tidak dimungkinkan adanya pelanggaran terhadap norma tersebut. Menurut Pasal 53 Konvensi Wina tahun 1969 tentang Hukum Perjanjian, yang dimaksud dengan jus cogens atau peremptory norm, adalah:

"... a peremptory norm of general international law is a norm accepted and recognized by the international community of States as a whole as a norm from which no derogation is permitted and which can be modified only by a subsequent norm of general international law having character."

Menurut Black's Law Dictionary, jus cogens diartikan sebagai suatu norma hukum internasional umum yang mengandung sifat perintah bahwa dua atau lebih negara tidak dapat membebaskan diri dari norma tersebut, yaitu:

"A mandatory or peremptory norm of general international law accepted and recognized by the international community as a norm from which no derogation is permitted" (Bryan A. Gardner, 2004:876).

Jus cogens memiliki otoritas hukum lebih besar dibanding sumber hukum internasional lain. Larangan penyiksaan atau pelanggaran HAM berat yang memiliki status jus cogens memiliki derajat yang lebih tinggi dalam hirarki internasional (Sefriani, 2011:75). Penyiksaan merupakan salah satu kejahatan yang tunduk pada yurisdiksi hukum internasional, sehingga untuk penyelesaiannya dapat diterapkan yurisdiksi universal. Berdasarkan hal tersebut setiap negara memiliki kewenangan untuk memproses secara hukum pelaku penyiksaan tanpa dibatasi oleh kewarganegaraan si pelaku maupun korbannya. Definisi penyiksaan dalam Deklarasi Tokyo 1975 dari World Medical Association adalah:

"Penyiksaan adalah tindakan kekerasan fisik dan atau mental yang dilakukan secara sepihak, sengaja dan sistematik oleh seseorang atau sekelompok orang lain yang menimbulkan perasaan tidak nyaman sampai dengan nyeri yang tidak tertahankan sehingga berakibat terjadinya cedera dan kerusakan sementara dan atau menetap pada tubuh maupun pada fungsi organ tubuh, serta gangguan psikiatrik berupa perasaan cemas, takut dan teror yang berlebihan, hilangnya harga diri atau jati diri, serta penyiksaan berat yang dapat menyebabkan kematian dan sebagainya" (World Medical Association. Declaration guidelines for medical doctors concerning torture and other cruel, inhuman or degrading treatment or punishment in relation to detention and imprisonment). 
Dalam instrumen hukum HAM internasional, penyiksaan secara khusus diatur dalam Konvensi Menentang Penyiksaan dan Perlakuan atau Penghukuman Lain yang Kejam, Tidak Manusiawi atau Merendahkan Martabat Manusia (Convention Against Torture and Other Cruel, Inhuman or Degrading Treatment or Punishment) tahun 1984. Tindakan penyiksaan menurut Konvensi Menentang Penyiksaan dan Perlakuan atau Hukuman Lain yang Kejam, Tidak Manusiawi dan Merendahkan Martabat Manusia dapat dirumuskan dalam Pasal 1 yang isinya :

"Penyiksaan berarti setiap perbuatan yang dilakukan dengan sengaja sehingga menimbulkan rasa sakit atau penderitaan yang hebat, baik jasmani maupun rohani, pada seseorang untuk memperoleh pengakuan atau keterangan dari orang itu atau dari orang ketiga, dengan menghukumnya atas suatu perbuatan yang telah dilakukan atau diduga telah dilakukan oleh orang itu atau orang ketiga, atau mengancam atau memaksa orang itu atau orang ketiga, atau untuk suatu alasan yang didasarkan pada diskriminasi, apabila rasa sakit dan penderitaan tersebut ditimbulkan oleh, atas hasutan dari, dengan persetujuan, atau sepengetahuan pejabat pemerintah. Hal itu tidak meliputi rasa sakit atau penderitaan yang timbul hanya dari, melekat pada, atau diakibatkan oleh sanksi hukum yang berlaku" (Lampiran Undang-Undang Republik Indonesia Nomor 5 Tahun 1998 Tentang Pengesahan Konvensi Menentang Penyiksaan Dan Perlakuan Atau Penghukuman Lain Yang Kejam, Tidak Manusiawi, Atau Merendahkan Martabat Manusia).

Dari penjelasan Pasal 1 tersebut terdapat 3 unsur pokok di dalam definisi penyiksaan, ketiga unsur tersebut antara lain harus adanya rasa sakit atau penderitaan terhadap jasmani atau raga maupun rohani atau jiwa yang luar biasa, harus ada suatu tujuan, harus ditimbulkan oleh dan atau hasutan dari atau dengan persetujuan atau sepengetahuan dari seseorang pejabat publik atau seseorang yang bertindak di dalam kapasitas pemerintahan. Perbedaan antara penyiksaan dan perlakuan tidak manusiawi atau merendahkan berasal dari intensitas penderitaan yang ditimbulkan. Tidak dapat dibenarkan dalam situasi tertentu melakukan perlakuan yang tidak manusiawi yang dapat menyebabkan penderitaan terhadap mental atau fisik seseorang (Pieter Van Dijk et. Al, 2006:405).

Kewajiban negara peratifikasi Konvensi Menentang Penyiksaan adalah mengambil langkah-langkah yang efektif baik secara legislatif, administratif, maupun yudisial untuk mencegah penyiksaan (Pasal 2 ayat (1) Konvensi Menentang Penyiksaan dan Perlakuan atau Hukuman Lain yang Kejam, Tidak Manusiawi dan Merendahkan Martabat Manusia). Tidak ada pengecualian apapun yang dapat menjadi pembenaran untuk melakukan penyiksaan (Pasal 2 ayat (2) Konvensi Menentang Penyiksaan dan Perlakuan atau Hukuman Lain yang Kejam, Tidak Manusiawi dan Merendahkan Martabat Manusia). Perintah atasan juga tidak dapat dijadikan sebagai pembenar untuk melakukan penyiksaan (Pasal 2 ayat (3) Konvensi Konvensi Menentang Penyiksaan dan Perlakuan atau Hukuman Lain yang Kejam, Tidak Manusiawi dan Merendahkan Martabat Manusia).

Negara peserta Konvensi Menentang Penyiksaan harus menjamin semua tindakan penyiksaan merupakan suatu kejahatan menurut hukum pidananya, termasuk percobaan untuk melakukan penyiksaan maupun tindakan untuk membantu atau turut serta dalam penyiksaan. Negara harus mengatur agar tindakan penyiksaan dapat dihukum dengan hukuman yang setimpal dengan mempertimbangkan sifat kejahatannya (Pasal 4 Konvensi Menentang Penyiksaan dan Perlakuan atau Hukuman Lain yang Kejam, Tidak Manusiawi dan Merendahkan Martabat Manusia).
Jurnal Yustika Vol. 23 No. 01, Jul 2020

Halaman | 40

Mekanisme Pengaduan Oleh Committee Against Torture Terkait Tindakan Penyiksaan Dan Perlakuan Yang Merendahkan Martabat Manusia

Aldo Rico Geraldi 
Jurnal Yustika

Vol. 23 No. 01, Juli 2020

Halaman | 41

Mekanisme

Pengaduan Oleh

Committee Against

Torture Terkait

Tindakan

Penyiksaan Dan

Perlakuan Yang

Merendahkan

Martabat Manusia

Aldo Rico Geraldi

\subsection{Komite Menentang Penyiksaan}

Komite Menentang Penyiksaan dibentuk berdasarkan pasal 17 dari Konvensi Menentang Penyiksaan dan Perlakuan atau Hukuman Lain yang Kejam, Tidak Manusiawi dan Merendahkan Martabat Manusia yang menyatakan bahwa harus dibentuk suatu Komite Menentang Penyiksaan yang selanjutnya disebut sebagai Komite. Komite tersebut terdiri dari sepuluh ahli yang bermoral tinggi dan diakui kemampuannya di bidang hak asasi manusia yang bertugas dalam kapasitas pribadinya. Komite Menentang Penyiksaan mulai bekerja pada tanggal 1 Januari 1988 (Fact Sheet No.17. The Committee Against Torture, A Monitoring Body).

Komite merupakan badan Perserikatan Bangsa-Bangsa yang dipercaya dapat mengawasi secara spesifik instrumen multilateral untuk perlindungan terhadap penyiksaan dan perlakuan tidak manusiawi lainnya. Konvensi Menentang Penyiksaan dan Perlakuan atau Hukuman Lain yang Kejam, Tidak Manusiawi dan Merendahkan Martabat Manusia menetapkan sejumlah kewajiban yang dirancang untuk memperkuat perlindungan hak asasi manusia dan kebebasan dasar serta memberikan kepada Komite Menentang Penyiksaan kekuasaan yang luas untuk melakukan pemeriksaan dan penyelidikan yang bertujuan untuk memastikan efektivitas keberadaan dari Komite tersebut (Fact Sheet No.17. The Committee Against Torture, A Monitoring Body).

Komite Menentang Penyiksaan terdiri dari sepuluh ahli yang bermoral tinggi dan diakui kemampuannya di bidang hak asasi manusia yang bertugas dalam kapasitas pribadinya untuk mengawasi pelaksanaan Konvensi Menentang Penyiksaan dan Perlakuan atau Hukuman Lain yang Kejam, Tidak Manusiawi dan Merendahkan Martabat Manusia (United Nations Human Rights. Committee Against Torture). Ahli-ahli tersebut dipilih oleh negara-negara pihak dengan pertimbangan pada pembagian geografis yang adil dan pada manfaat dari keikutsertaan mereka yang mempunyai pengalaman hukum (Pasal 17 ayat (1) Konvensi Menentang Penyiksaan dan Perlakuan atau Hukuman Lain yang Kejam, Tidak Manusiawi dan Merendahkan Martabat Manusia).

Para anggota Komite dipilih melalui pemungutan suara secara rahasia berdasarkan daftar orang-orang yang dicalonkan oleh negara-negara pihak. Setiap negara pihak dapat mencalonkan satu orang warga negaranya. Negara pihak mempertimbangkan manfaat pencalonan orang-orang yang juga menjadi anggota Komite Hak Asasi Manusia yang didirikan menurut Kovenan Internasional tentang Hak Sipil dan Politik yang bersedia bertugas dalam Komite Menentang Penyiksaan (Pasal 17 ayat (2) Konvensi Menentang Penyiksaan dan Perlakuan atau Hukuman Lain yang Kejam, Tidak Manusiawi dan Merendahkan Martabat Manusia).

Pemilihan para anggota Komite dilakukan pada sidang dua tahunan antar negara pihak yang diadakan oleh Sekretaris Jenderal Perserikatan Bangsa-Bangsa. Orang-orang yang terpilih sebagai anggota Komite adalah mereka yang memperoleh suara terbanyak dan mayoritas mutlak dari suara para wakil negara-negara pihak yang hadir dan memberikan suara (Pranoto Iskandar, 2012). Pemilihan pertama harus diadakan paling lambat enam bulan setelah tanggal diberlakukannya Konvensi Menentang Penyiksaan dan Perlakuan atau Hukuman Lain yang Kejam, Tidak Manusiawi dan Merendahkan Martabat Manusia. Sekurang-kurangnya empat bulan sebelum tanggal setiap pemilihan, Sekretaris Jenderal Perserikatan Bangsa-Bangsa mengirimkan surat kepada negara-negara pihak agar dalam waktu tiga bulan mereka sudah mengajukan calon-calonnya (Pasal 17 ayat (4) Konvensi Menentang Penyiksaan dan Perlakuan atau Hukuman Lain yang Kejam, Tidak Manusiawi dan Merendahkan Martabat Manusia). 
Sekretaris Jenderal mempersiapkan suatu daftar menurut abjad semua calon beserta negara-negara pihak yang mencalonkannya dan kemudian mengajukannya kepada negaranegara pihak lainnya. Para anggota Komite dipilih untuk masa jabatan empat tahun (Rhona K. M. Smith, 2010:71). Apabila seorang anggota Komite meninggal atau mengundurkan diri atau karena suatu alasan tidak dapat lagi menjalankan tugasnya, maka negara pihak yang mencalonkannya harus menunjuk seorang ahli lain di antara warganegaranya untuk bertugas selama sisa masa jabatannya (Pasal 17 ayat (6) Konvensi Menentang Penyiksaan dan Perlakuan atau Hukuman Lain yang Kejam, Tidak Manusiawi dan Merendahkan Martabat Manusia).

Komite menetapkan aturan tata kerjanya sendiri yang menentukan bahwa anggota Komite merupakan suatu kuorum dan keputusan-keputusan Komite diambil dengan suara mayoritas dari para anggota yang hadir. Sekretaris Jenderal Perserikatan Bangsa-Bangsa menyediakan staf dan fasilitas yang diperlukan Komite agar dapat melaksanakan tugasnya secara efektif. Sekretaris Jenderal Perserikatan Bangsa-Bangsa menyelenggarakan sidang pertama Komite. Setelah sidang pertama, Komite mengadakan pertemuan pada waktu-waktu yang ditetapkan dalam peraturan tata kerjanya (Pasal 18 Konvensi Menentang Penyiksaan dan Perlakuan atau Hukuman Lain yang Kejam, Tidak Manusiawi dan Merendahkan Martabat Manusia).

Komite mengadakan dua kali sidang dalam waktu satu tahun. Selain itu, Komite dapat mengadakan sidang khusus atas permintaan mayoritas anggota atau atas permintaan negara peserta. Sidang diadakan di markas Perserikat Bangsa-Bangsa, Jenewa. Sidang diadakan secara terbuka kecuali Komite memutuskan sebaliknya (Rhona K. M. Smith, 2010). Negara-negara pihak harus menanggung pembiayaan yang timbul berkenaan dengan penyelenggaraan rapat yang dilakukan oleh negara-negara pihak dan Komite, termasuk penggantian pembayaran kepada Perserikatan Bangsa-Bangsa atas semua pengeluaran, seperti biaya staf dan fasilitas yang telah dikeluarkan oleh Perserikatan Bangsa-Bangsa sesuai dengan Pasal 3 Konvensi Menentang Penyiksaan dan Perlakuan atau Hukuman Lain yang Kejam, Tidak Manusiawi dan Merendahkan Martabat Manusia (Pasal 18 ayat (5) Konvensi Menentang Penyiksaan dan Perlakuan atau Hukuman Lain yang Kejam, Tidak Manusiawi dan Merendahkan Martabat Manusia).

Komite dapat mengundang badan-badan khusus, badan-badan PBB yang bersangkutan, organisasi antar pemerintah daerah dan organisasi non-pemerintah dengan status konsultatif dengan Dewan Ekonomi dan Sosial untuk menyerahkan suatu informasi, dokumentasi dan pernyataan tertulis, yang sesuai dan relevan dengan kegiatan Komite Menentang Penyiksaan berdasarkan Konvensi Menentang Penyiksaan dan Perlakuan atau Hukuman Lain yang Kejam, Tidak Manusiawi dan Merendahkan Martabat Manusia (Fact Sheet No.17. The Committee Against Torture, The Committee At Wor).

Berdasarkan Pasal 19 negara-negara pihak akan menyerahkan kepada Komite melalui Sekretaris Jenderal Perserikatan Bangsa-Bangsa mengenai laporan tentang tindakan-tindakan yang telah mereka ambil dalam rangka penerapan Konvensi. Setelah itu negara-negara pihak menyerahkan laporan pelengkap setiap empat tahun sekali tentang setiap langkah baru yang diambil dan laporan-laporan lain yang mungkin diminta Komite. Sekretaris Jenderal Perserikatan Bangsa-Bangsa harus meneruskan laporan-laporan tersebut kepada semua negara pihak (Rhona K. M. Smith, 2010:71).

Pada saat penilaian, Komite akan mengundang perwakilan dari negara peserta untuk mengadakan tanya jawab. Komite akan melakukan penilaian terhadap laporan yang diterima 
Jurnal Yustika

Vol. 23 No. 01, Juli 2020

Halaman | 43

Mekanisme

Pengaduan Oleh

Committee Against

Torture Terkait

Tindakan

Penyiksaan Dan

Perlakuan Yang

Merendahkan

Martabat Manusia

Aldo Rico Geraldi dan apabila dipandang kurang maka Komite akan meminta informasi tambahan. Setelah penilaian selesai maka Komite akan membuat sebuah komentar umum yang kemudian negara peserta berhak untuk memberikan pandangannya atas komentar tersebut (Pranoto Iskandar, 2012:515). Komite dapat memutuskan untuk memasukkan setiap komentar yang dibuatnya sesuai dengan Pasal 19 ayat (3) bersamaan dengan observasi terhadap komentar yang diberikan oleh negara pihak yang bersangkutan ke dalam laporan tahunan yang disusun sesuai dengan Pasal 24. Jika diminta oleh negara pihak yang bersangkutan, Komite juga dapat menyertakan salinan laporan yang diajukan berdasarkan Pasal 19 ayat (1) Konvensi Menentang Penyiksaan dan Perlakuan atau Hukuman Lain yang Kejam, Tidak Manusiawi dan Merendahkan Martabat Manusia.

Negara Pihak mempunyai kewajiban untuk melaporkan pelaksanaan Konvensi yang telah diratifikasinya secara berkala kepada Komite. Untuk keperluan tersebut Komite telah mempersiapkan petunjuk pelaksanaan untuk membantu negara-negara peserta dalam pengerjaan dan presentasi laporan. Petunjuk pelaksanaan ini bertujuan juga untuk membuat seragam presentasi laporan-laporan, sehingga memudahkan Komite dalam melaksanakan tugasnya, serta memberi gambaran secara jelas kepada semua negara peserta untuk melaksanakan kewajiban-kewajibannya berdasarkan Konvensi Menentang Penyiksaan dan Perlakuan atau Hukuman Lain yang Kejam, Tidak Manusiawi dan Merendahkan Martabat Manusia (Agung Yudha Wiranata, 2005:4).

Laporan periodik yang diserahkan kepada Komite Menentang Penyiksaan setiap empat tahun harus terdiri dari beberapa bagian. Pada bagian pertama, harus memuat segala langkahlangkah yang telah diambil untuk meningkatkan efektifitas Konvensi serta segala perkembangan yang telah terjadi pada saat laporan dibuat. Selain itu pada bagian ini pun harus memuat segala perubahan dalam perundangan-undangan nasional, kasus yang relevan, pengaduan dan segala kesulitan atau hambatan yang ditemui (Pranoto Iskandar, 2012:514-515).

Laporan harus secara tepat menunjukkan status Konvensi Menentang Penyiksaan dan Perlakuan atau Hukuman Lain yang Kejam, Tidak Manusiawi dan Merendahkan Martabat Manusia telah menjadi bagian hukum nasional. Bila tidak, laporan harus memperinci apakah ratifikasi atau persetujuan atas Konvensi tersebut membawa akibat masuknya Konvensi ke dalam hukum nasional dan kewajiban dari alat-alat negara untuk secara langsung menerapkan ketetapan-ketetapan Konvensi serta memungkinkan individu untuk menuntut secara langsung hak-hak yang diperuntukkan baginya oleh Konvensi.

Selain itu, laporan harus menguraikan struktur organisasi dari negara peserta, yaitu kekuasaan legislatif, eksekutif, dan yudikatif serta tanggung jawabnya. Bagian ini harus melaporkan otoritas yudisial, administratif, atau lainnya yang bertanggung jawab untuk menerapkan berbagai ketetapan dari Konvensi dan menilai situasi yang berhubungan dengan penyiksaan dalam negara pelapor, dan bilamana penyiksaan masih terjadi, laporan harus memberi alasan-alasan mengapa penyiksaan masih dilakukan. Selanjutnya bagian ini harus menyatakan apakah ketetapan-ketetapan Konvensi dapat digunakan dan diterapkan langsung oleh pengadilan-pengadilan, mahkamah-mahkamah lainnya, atau otoritas administratif serta apakah ketetapan-ketetapan ini harus diubah lebih dahulu menjadi hukum internasional atau peraturan administratif jika hendak diterapkan oleh otoriras yang bersangkutan (Agung Yudha Wiranata, 2005:5).

Bagian selanjutnya, laporan tersebut harus memuat segala informasi tambahan yang diminta oleh Komite dan memuat informasi mengenai berbagai langkah-langkah yang telah 
diambil oleh negara peserta untuk memenuhi usulan-usulan Komite di masa sebelumnya serta harus menyediakan informasi mengenai penerapan Konvensi (Pranoto Iskandar, 2012:514-515). Laporan harus menyediakan informasi dan penerapan mengenai langkah-langkah legislatif, administratif, dan yudisial yang telah diambil untuk memberi penilaian pada ketetapanketetapan dari pasal tersebut. Laporan harus mencakup informasi statistik dan menyebut tiap kasus pelanggaran serta langkah-langkah yang diambil untuk menyelesaikan pelanggaran tersebut.

\subsection{Mekanisme pengaduan yang diatur Komite Menentang Penyiksaan}

Komite Menentang Penyiksaan memiliki mandat terkait dengan penilaian atas pengaduan oleh negara peserta terhadap negara peserta lainnya dengan adanya dugaan telah terjadi tindakan penyiksaan terkait dengan kewenangan Komite untuk menerima komunikasi yang diajukan oleh individu serta terkait dengan pencarian fakta sebagai akibat adanya bukti apabila di negara peserta telah terjadi praktek penyiksaan (Pranoto Iskandar, 2012:514).

Prosedur pengaduan dalam hukum internasional secara umum merujuk pada sebuah proses hukum formal dimana seseorang atau sekelompok orang mengajukan pengaduan kepada badan hukum internasional untuk mengungkapkan bahwa hak asasi mereka telah dilanggar dalam suatu kasus tertentu. Mekanisme pengaduan internasional dirancang untuk menangani kasus-kasus pelanggaran negara atas kewajiban mereka di bawah hukum internasional. Prosedur ini tidak dimaksudkan untuk menjadi upaya perlindungan yang utama, melainkan pengaduan hanya diterapkan pada kondisi jika tidak dimungkinkan untuk mendapatkan penyelesaian di tingkat nasional (Agung Yudha Wiranata, 2005:11).

Prosedur pengaduan yang diterima oleh Komite Menentang Penyiksaan hanya dapat dilakukan dan berlaku dalam hal negara peserta telah mengakui kewenangan Komite untuk menerima dan mempertimbangkan pengaduan yang menyebutkan bahwa suatu negara pihak menyatakan bahwa suatu negara pihak lain tidak memenuhi kewajiban-kewajibannya berdasarkan Konvensi. Komite juga tidak berhak menerima dan membahas laporan pengaduan dari seseorang, kecuali jika Komite menyatakan bahwa pengaduan tersebut belum pernah atau tidak sedang dibahas oleh prosedur penyelesaian atau penyelidikan internasional lainnya dan perorangan yang dimaksudkan sudah menggunakan segala upaya penyelesaian hukum di dalam negerinya.

Kompetensi yang diberikan kepada Komite oleh Konvensi Menentang Penyiksaan dan Perlakuan atau Hukuman Lain yang Kejam, Tidak Manusiawi dan Merendahkan Martabat Manusia adalah bersifat opsional. Pada saat meratifikasi atau mengaksesi Konvensi, suatu negara dapat menyatakan bahwa ia tidak mengakui keberadaan Pasal tertentu. Dalam hal negara melakukan reservasi terhadap Pasal 20 Konvensi, maka Komite tidak dapat melaksanakan kekuasaan yang diberikan kepadanya untuk melakukan pencarian fakta apabila mendapat informasi yang dapat dipercaya mengenai telah terjadinya tindak penyiksaan secara sistematis di salah satu negara peserta

\section{Pengaduan Antar Negara}

Pengaduan antar negara hanya berlaku dalam hal negara peserta telah mengakui kewenangan Komite untuk menerima dan mempertimbangkan pengaduan yang menyebutkan bahwa suatu negara pihak menyatakan bahwa suatu negara pihak lain tidak memenuhi kewajiban-kewajibannya berdasarkan Konvensi Menentang Penyiksaan dan Perlakuan atau Hukuman Lain yang Kejam, Tidak Manusiawi dan Merendahkan
Jurnal Yustika Vol. 23 No. 01, Jul 2020

Halaman | 44

Mekanisme

Pengaduan Oleh

Committee Against

Torture Terkait Tindakan

Penyiksaan Dan

Perlakuan Yang Merendahkan

Martabat Manusia

Aldo Rico Geraldi 
Jurnal Yustika

Vol. 23 No. 01, Juli 2020

Halaman | 45

Mekanisme

Pengaduan Oleh

Committee Against

Torture Terkait

Tindakan

Penyiksaan Dan

Perlakuan Yang

Merendahkan

Martabat Manusia

Aldo Rico Geraldi
Martabat Manusia. Apabila suatu negara pihak berpendapat bahwa suatu negara pihak lain tidak menjalankan ketentuan-ketentuan Konvensi, negara tersebut melalui komunikasi tertulis dapat mengangkat persoalan itu agar diperhatikan oleh negara pihak yang bersangkutan (Rhona K. M. Smith, 2010:71).

Dalam jangka waktu tiga bulan negara penerima harus memberikan penjelasannya kepada negara yang mengirimkan pengaduan. Apabila kedua belah pihak tidak merasa puas, maka dalam waktu enam bulan sejak diterimanya pengaduan awal, negara pihak dan negara penerima berhak menyerahkan permasalahannya kepada Komite, melalui pemberitahuan yang disampaikan kepada Komite dan kepada negara lain (Pasal 21 Konvensi Menentang Penyiksaan dan Perlakuan atau Hukuman Lain yang Kejam, Tidak Manusiawi dan Merendahkan Martabat Manusia).

Komite akan menangani masalah yang diserahkan kepadanya berdasarkan Pasal 21 Konvensi Menentang Penyiksaan dan Perlakuan atau Hukuman Lain yang Kejam, Tidak Manusiawi dan Merendahkan Martabat Manusia hanya setelah Komite memastikan bahwa semua langkah perbaikan dalam negeri telah diupayakan dan digunakan sepenuhnya untuk masalah ini, sesuai dengan prinsip-prinsip hukum internasional yang diakui secara umum, penilaian akan diadakan dalam sebuah sidang tertutup. Komite akan menyediakan jasa-jasa baik bagi kedua belah pihak dengan maksud untuk memecahkan permasalahan atas dasar penghormatan terhadap kewajiban-kewajiban yang ditetapkan dalam Konvensi (Pranoto Iskandar, 2012:516).

Negara-negara pihak yang terlibat sengketa berhak untuk memberikan pandangannya secara lisan atau tertulis apabila masalah tersebut dibahas oleh Komite. Komite dalam jangka waktu dua belas bulan setelah diterimanya pemberitahuan harus menyampaikan suatu laporan (Pasal 21 ayat (1) huruf h Konvensi Menentang Penyiksaan dan Perlakuan atau Hukuman Lain yang Kejam, Tidak Manusiawi dan Merendahkan Martabat Manusia).

Apabila penyelesaian dengan jasa-jasa baik dapat tercapai, maka Komite membatasi laporannya pada pernyataan singkat tentang fakta dan penyelesaian yang dicapai, tetapi apabila tidak tercapai, Komite membatasi laporannya pada pernyataan singkat tentang fakta pengajuan tertulis dan rekaman mengenai pengajuan-pengajuan lisan yang disampaikan oleh negara-negara pihak yang bersangkutan, yang dilampirkan pada laporan tersebut. Dalam setiap penanganan masalah, laporan akan dikomunikasikan kepada negara-negara pihak yang bersangkutan. Komite dapat memanggil kedua belah pihak untuk memberikan informasi tambahan. (Pranoto Iskandar, 2012:516).

\section{Pengaduan Individu}

Negara pihak sesuai dengan ketentuan Pasal 22 dapat membuat deklarasi mengakui kewenangan Komite untuk menerima dan membahas laporan pengaduan dari atau atas nama pribadi atau individu yang berada dalam yurisdiksinya, yang menyatakan diri menjadi korban pelanggaran yang dilakukan negara pihak terhadap Konvensi. Komite tidak berhak menerima dan membahas laporan pengaduan jika menyangkut suatu negara pihak yang tidak membuat deklarasi (M. Ghufran H. Kordi K, 2013:221). 
Komite juga tidak berhak menerima dan membahas laporan pengaduan dari seseorang, kecuali jika Komite menyatakan bahwa pengaduan tersebut belum pernah atau tidak sedang dibahas oleh prosedur penyelesaian atau penyelidikan internasional lainnya dan perorangan yang dimaksudkan sudah menggunakan segala upaya penyelesaian hukum di dalam negerinya. Selain itu Komite tidak menerima laporan pengaduan berdasarkan pasal ini yang tidak jelas pengirimnya dan tidak ditandatangani atau yang dianggap Komite sebagai penyalahgunaan hak pengajuan pengaduan yang bertentangan dengan ketentuan-ketentuan Konvensi Menentang Penyiksaan dan Perlakuan atau Hukuman Lain yang Kejam, Tidak Manusiawi dan Merendahkan Martabat Manusia (Rhona K. M. Smith, 2010:72).

Pengaduan tidak akan dicatat oleh Sekertaris dalam hal ditujukan kepada negara yang tidak mengakui kewenangan Komite, tidak memuat identitas, yang mengajukan bukan korban atau saudara atau perwakilan yang mendapatkan kuasa untuk itu dari korban. Pengaduan harus memuat berbagai informasi seperti identitas, negara peserta yang diadukan, objek pengaduan, ketentuan yang dilanggar, fakta kejadian, berbagai langkah hukum yang telah dilakukan dan harus menjelaskan sampai mana hal ini dipersoalkan oleh mekanisme internasional lainnya (Pranoto Iskandar, 2012:516).

Penilaian terhadap pengaduan akan dilakukan dalam sebuah sidang tertutup. Anggota Komite dituntut untuk mengundurkan diri dari penilaian apabila memiliki kemungkinan merusak imparsialitas penilaian Komite. Untuk menentukan layak tidaknya sebuah pengaduan, Komite akan membentuk sebuah kelompok kerja untuk melakukan penilaian. Kelompok kerja terdiri dari tiga sampai lima orang anggota (Pranoto Iskandar, 2012:516). Jika Komite memutuskan bahwa pengaduan dapat diterima, maka dalam waktu enam bulan, negara penerima harus mengajukan kepada Komite penjelasan tertulis atau pernyataan-pernyataan yang menjernihkan permasalahan dan langkah perbaikan yang mungkin telah dilakukan oleh negara tersebut (Pasal 22 ayat (3) Konvensi Menentang Penyiksaan dan Perlakuan atau Hukuman Lain yang Kejam, Tidak Manusiawi dan Merendahkan Martabat Manusia).

Untuk menindaklanjuti keputusan yang dihasilkan, Komite membentuk seorang atau lebih pelapor untuk mengawasi apakah keputusan tersebut dijalankan atau tidak. Individu yang mengajukan pengaduan juga dapat mengajukan pengamatannya atau informasi tambahan kepada Komite. Selain itu, individu yang mengajukan pengaduan atau wakilnya dan perwakilan negara peserta sidang Komite dapat hadir pada pertemuan tertutup untuk memberikan klarifikasi mengenai kasus pelanggaran yang terjadi (Fact Sheet No.17. The Committee Against Torture, Individual Complaints).

\section{Pencarian Fakta}

Komite dapat melakukan pencarian fakta apabila mendapat informasi yang dapat dipercaya mengenai telah terjadinya tindak penyiksaan secara sistematis di salah satu negara peserta (M. Ghufran H. Kordi K, 2013:221). Kompetensi yang diberikan kepada Komite adalah bersifat opsional. Pada saat meratifikasi atau mengaksesi Konvensi, suatu negara dapat menyatakan bahwa ia tidak mengakui keberadaan Pasal tertentu. Dalam hal negara melakukan reservasi terhadap Pasal 20, maka Komite tidak dapat melaksanakan kekuasaan yang diberikan kepadanya (Fact Sheet No.17. The Committee Against Torture, Powers of investigation of the Committee). 
Jurnal Yustika

Vol. 23 No. 01, Juli 2020

Halaman | 47

Mekanisme

Pengaduan Oleh

Committee Against

Torture Terkait

Tindakan

Penyiksaan Dan

Perlakuan Yang

Merendahkan

Martabat Manusia

Aldo Rico Geraldi
Setelah mendapatkan berbagai informasi dari negara yang bersangkutan, Komite dapat membentuk satu atau lebih anggotanya untuk mengadakan pencarian fakta dan segera melaporkan hasilnya kepada Komite. Apabila dipandang perlu dengan persetujuan negara yang bersangkutan, Komite dapat mengadakan kunjungan ke negara peserta (Malcolm N. Shaw Qc, 2013:296-297). Komite melalui Sekertaris Jenderal akan meminta persetujuan negara peserta dan jaminan agar tidak dihalang-halangi dalam menjalankan tugasnya. Setelah pencarian selesai dan diuji oleh Komite, maka laporannya akan diserahkan kepada negara peserta yang bersangkutan.

Negara peserta kemudian akan diundang untuk mengetahui bagaimana tanggapan yang diberikan oleh negara tersebut. Komite dapat memutuskan untuk meminta informasi tambahan baik dari perwakilan negara yang bersangkutan atau dari organisasi pemerintah dan non-pemerintah maupun individu yang bertujuan untuk memperoleh informasi. Komite diijinkan untuk membuat ringkasan dalam laporan tahunannya apabila telah dilakukan pembahasan terlebih dahulu dengan negara peserta yang bersangkutan (Pranoto Iskandar, 2012:516). Negara pihak bisa memilih keluar dari prosedur ini jika mereka menghendakinya pada saat pelaksanaan penandatanganan, ratifikasi, atau pengesahan (Malcolm N. Shaw Qc, 2013:297).

Penentuan keabsahan informasi ada di kewenangan Komite. Informasi tidak dapat ditindaklanjuti dalam hal negara peserta yang melakukan reservasi terhadap Pasal 20. Oleh karena China melakukan reservasi terhadap Pasal tersebut, maka mekanisme penyelidikan independen yang bersifat rahasia yang sesungguhnya menjadi kewenangan Komite, tidak dapat diterapkan.

\section{Kesimpulan}

Penyiksaan sebagai suatu perbuatan yang dilakukan dengan menimbulkan rasa sakit atau penderitaan terhadap jasmani atau raga maupun rohani atau jiwa yang luar biasa. Penyiksaan tersebut harus dilakukan dengan suatu tujuan, harus ditimbulkan oleh dan atau hasutan dari atau dengan persetujuan atau sepengetahuan dari seseorang pejabat publik atau seseorang yang bertindak di dalam kapasitas pemerintahan. Majelis Umum Perserikatan Bangsa-Bangsa kemudian membentuk Konvensi Menentang Penyiksaan dan Perlakuan atau Hukuman Lain yang Kejam, Tidak Manusiawi dan Merendahkan Martabat Manusia pada tanggal 10 Desember 1984 yang bertujuan untuk mengurangi penyiksaan yang terjadi.

Konvensi Menentang Penyiksaan dan Perlakuan atau Hukuman Lain yang Kejam, Tidak Manusiawi dan Merendahkan Martabat Manusia menyatakan bahwa harus dibentuk suatu Komite Menentang Penyiksaan. Komite merupakan badan Perserikatan Bangsa-Bangsa yang dipercaya dapat mengawasi secara spesifik instrumen multilateral untuk perlindungan terhadap penyiksaan dan perlakuan tidak manusiawi lainnya. Konvensi Menentang Penyiksaan dan Perlakuan atau Hukuman Lain yang Kejam, Tidak Manusiawi dan Merendahkan Martabat Manusia menetapkan sejumlah kewajiban yang dirancang untuk memperkuat perlindungan hak asasi manusia dan kebebasan dasar serta memberikan kekuasaan yang luas untuk melakukan pemeriksaan dan penyelidikan.

Komite Menentang Penyiksaan memiliki mandat terkait dengan penilaian atas pengaduan oleh negara peserta terhadap negara peserta lainnya dengan adanya dugaan telah terjadi tindakan penyiksaan. Mekanisme pengaduan yang diatur oleh Komite Menentang Penyiksaan antara lain berupa pengaduan antar negara hanya berlaku dalam hal negara peserta 
telah mengakui kewenangan Komite untuk menerima dan mempertimbangkan pengaduan yang menyebutkan bahwa suatu negara pihak menyatakan bahwa suatu negara pihak lain tidak memenuhi kewajiban-kewajibannya berdasarkan Konvensi Menentang Penyiksaan dan Perlakuan atau Hukuman Lain yang Kejam, Tidak Manusiawi dan Merendahkan Martabat Manusia. Selain itu dilakukan dengan mekanisme pengaduan individu bahwa Negara pihak dapat membuat deklarasi mengakui kewenangan Komite untuk menerima dan membahas laporan pengaduan dari atau atas nama pribadi atau individu yang berada dalam yurisdiksinya, yang menyatakan diri menjadi korban pelanggaran yang dilakukan negara pihak terhadap Konvensi. Selanjutnya, mekanisme yang dilakukan bahwa Komite dapat melakukan pencarian fakta apabila mendapat informasi yang dapat dipercaya mengenai telah terjadinya tindak penyiksaan secara sistematis di salah satu negara peserta. Namun, Prosedur pengaduan yang diterima oleh Komite Menentang Penyiksaan hanya dapat dilakukan dan berlaku dalam hal negara peserta telah menjadi negara peserta Konvensi dan mengakui kewenangan Komite, pengaduan tersebut belum pernah atau tidak sedang dibahas oleh prosedur penyelesaian atau penyelidikan internasional lainnya dan telah menggunakan segala upaya penyelesaian hukum di dalam negeri, serta negara peserta tidak melakukan reservasi terhadap pasal tertentu dalam Konvensi yang mengatur kewenangan Komite untuk melakukan penyelidikan.

\section{Daftar Referensi}

$\underline{\text { Buku }}$

Dijk, Pieter Van et. al. (2006). Theory and Practice of the European Convention on Human Rights. Antwerpen: Intersentia.

Gardner, Bryan A. (2004). Black's Law Dictionary. Dallas: Thomson West.

Iskandar, Pranoto. (2012). Hukum HAM Internasional Sebuah Pengantar Kontekstual. Cianjur: IMR Press.

Kordi, M. Ghufran H. K. (2013). HAM Tentang Perbudakan, Peradilan, Kejahatan Kemanusiaan $\mathcal{E}$ Perang. Yogyakarta: Graha Ilmu.

Qc, Malcolm N. Shaw. (2013). Hukum Internasional. Bandung: Nusa Media.

Smith, Rhona K. M. (2010). Textbook on International Human Rights. New York: Oxford University Press.

Sefriani. (2011). Hukum Internasional Suatu Pengantar. Jakarta: RajaGrafindo Persada.

Wiranata, Agung Yudha. (2005). Konvensi Anti Penyiksaan. Jakarta: Lembaga Studi dan Advokasi Masyarakat.

\section{Peraturan Perundang-Undangan dan Instrumen Internasional}

Undang-Undang Republik Indonesia Nomor 5 Tahun 1998 Tentang Pengesahan Konvensi Menentang Penyiksaan Dan Perlakuan Atau Penghukuman Lain Yang Kejam, Tidak Manusiawi, Atau Merendahkan Martabat Manusia (Convention Against Torture And Other, Cruel, Inhuman Or Degrading Treatment Or Punishment).

Convention against Torture and Other Cruel, Inhuman or Degrading Treatment or Punishment. Adopted and opened for signature, ratification and accession by General Assembly resolution 39/46 of 10 December 1984 entry into force 26 June 1987, in accordance with article 27 (1). 
Jurnal Yustika

Vol. 23 No. 01, Juli 2020

Halaman | 49

Mekanisme

Pengaduan Oleh

Committee Against

Torture Terkait

Tindakan

Penyiksaan Dan

Perlakuan Yang

Merendahkan

Martabat Manusia

Aldo Rico Geraldi

\section{Artikel Jurnal}

Aldo Rico Geraldi. (2017). Yuridical Analysis To The Concept Of Exclusive Economic Zones And Continental Shelf Relating To The Island Of Senkaku / Diaoyu Between Japan And China Based On The United Nations Convention On The Law Of The Sea 1982. Jurnal Komunikasi Hukum, 3(2): 1-17 ISSN: 2407-4276

Aldo Rico Geraldi. (2017). Penyelesaian Sengketa Investasi Melalui International Centre For Settlement Of Investment Dispute (Studi Kasus Pemerintah Indonesia Vs Churchill Mining). Tanjungpura Law Journal, 1(2): 89-113 DOI: http://dx.doi.org/10.26418/tlj.v1i2.24252.

Ratna Artha Windari dan Aldo Rico Geraldi. (2017). Kedaulatan Dan Suksesi Negara Terkait Dengan Asas Pacta Tertiis Nec Nocent Nec Prosunt Dalam Hal Pemisahan Timor Timur Dari Wilayah Republik Indonesia. Arena Hukum, 10(3): 480-502 DOI: https://doi.org/10.21776/ub.arenahukum.2017.01003.8.

\section{Artikel Internet}

Fact Sheet No.17. The Committee Against Torture, Introduction. Available online from: http://www.ohchr.org/Documents/Publications/FactSheet17en.pdf. [Accessed May 18, 2020].

Fact Sheet No.17. The Committee Against Torture, A Monitoring Body. Available online from: http://www.ohchr.org/Documents/Publications/FactSheet17en.pdf. [Accessed May 18, 2020].

Fact Sheet No.17. The Committee Against Torture, The Committee At Work. Available online from: http://www.ohchr.org/Documents/Publications/FactSheet17en.pdf. [Accessed May 18, 2020].

Fact Sheet No.17. The Committee Against Torture, Powers of investigation of the Committee. Available online from: http://www.ohchr.org/Documents/Publications/FactSheet17en.pdf. [Accessed May 18, 2020].

Fact Sheet No.17. The Committee Against Torture, Individual Complaints. Available online from: http://www.ohchr.org/Documents/Publications/FactSheet17en.pdf. [Accessed May 18, 2020].

Institute for Policy Research and Advocacy. Optional Protocol Convention Againts Torture. Available online from: http://www.elsam.or.id/new $/$ ?act=view\&id=306\&cat=c/6024\&lang=en. [Accessed May 18, 2020].

United Nations Human Rights. Committee Against Torture. Available online from: http://www.ohchr.org/EN/HRBodies/CAT/Pages/CATIndex.aspx. [Accessed May 18, 2020].

United Nations Human Rights. Status of Ratification Convention against Torture and Other Cruel, Inhuman or Degrading Treatment or Punishment. Available online from: http://indicators.ohchr.org/. [Accessed May 18, 2020].

World Medical Association. Declaration guidelines for medical doctors concerning torture and other cruel, inhuman or degrading treatment or punishment in relation to detention and imprisonment. Available online from: https://www.wma.net/policies-post/wma-declaration-of-tokyoguidelines-for-physicians-concerning-torture-and-other-cruel-inhuman-or-degradingtreatment-or-punishment-in-relation-to-detention-and-imprisonment/. [Accessed May $18,2020]$. 